\title{
UCLA
}

Mester

Title

Bodas De Perros

Permalink

https://escholarship.org/uc/item/1b4871pd

Journal

Mester, 20(1)

Author

Mester, [No author]

Publication Date

1991

DOI

10.5070/M3201014134

Copyright Information

Copyright 1991 by the author(s). All rights reserved unless otherwise indicated. Contact the author(s) for any necessary permissions. Learn more at https://escholarship.org/terms

Peer reviewed 


\section{Bodas De Perros}

Caso casado casó

Casi su esposa con hermano mayor

Incesto incierto cierto ocurrió

Cierto caso casado con cuñada menor

Los pájaros que asistieron a la ceremonia

Cantaron la vergüenza ante el altar mayor

En honor a la perra que su casi marido cedió.

El día de la boda allí se acudió

A mirar el arrastre y ladrido

Llenos de estupor.

La perra miraba llena de pudor,

$\mathrm{Al}$ saberse entregada a tan monstruo mayor.

Los palos del pueblo detrás de la pareja

Corrían

Enganchada por traseros y bolas

La sangre brotaba

Los pájaros cantaban

En todo su horror.

Aullidos se oían

Sonidos de nota

En todo color. 